OPEN ACCESS

Edited by:

Donatella Di Corrado, Kore University of Enna, Italy

Reviewed by:

Francesca Vitali,

University of Verona, Italy Valentina Perciavalle,

University of Catania, Italy

*Correspondence:

Antonio Baena-Extremera abaenaextrem@ugr.es

Specialty section: This article was submitted to Movement Science and Sport Psychology, a section of the journa Frontiers in Psychology

Received: 04 September 2019 Accepted: 23 October 2019 Published: 21 November 2019

Citation: Baños R, Baena-Extremera $A$ and Ortiz-Camacho M (2019) Prediction of the Satisfaction With the Student Life, Based on Teaching Competence and Satisfaction With the School. Front. Psychol. 10:2506. doi: 10.3389/fpsyg.2019.02506

\section{Prediction of the Satisfaction With the Student Life, Based on Teaching Competence and Satisfaction With the School}

\author{
Raúl Baños ${ }^{1}$, Antonio Baena-Extremera ${ }^{2 \star}$ and María del Mar Ortiz-Camacho ${ }^{2}$ \\ ${ }^{1}$ Department of Physical Education and Sports Science, Autonomous University of Baja California, Ensenada, Mexico, \\ ${ }^{2}$ Department of Didactic of Corporal Expression, Faculty of Education Sciences, University of Granada, Granada, Spain
}

The aim of this article was to assess how students evaluate the professional personality competence of physical education teachers in high school and its relation to student satisfaction and student satisfaction with life itself. In line with these aims, this study was completed as a cross-sectional study, which was carried out in a group of 890 physical education students. Of the study group, $50.3 \%$ were female and $49.7 \%$ were male. The average age was 15.49 years for females (SD 1.79) and 15.00 years for males (SD 2.00). We used a questionnaire featuring the Physical Education Teacher Competence, Intrinsic Satisfaction Classroom Scale, and Satisfaction with Life Scale. The results are presented as descriptive statistics, correlations, and a structural equation modeling analysis showing students' perceived competence, predicted self-determined satisfaction, which in turn corresponds to life satisfaction.

Keywords: teacher competences, classroom satisfaction, life satisfaction, student, physical education

\section{INTRODUCTION}

In recent years, diverse research has highlighted the importance of studying the life satisfaction of students, for the academic and personal repercussions that these carry (Méndez-Giménez et al., 2017; Salvador-Ferrer, 2017). For that, several authors (Diener, 1984; Diener and Emmons, 1985; Argyle, 1987) have used the theory of subjective well-being to study the satisfaction of people, identifying two dimensions namely: cognitive and affective dimensions. With this theory, subjective well-being can be understood as a theoretical construct that contemplates the combination of the cognitive process (judgments of satisfaction and dissatisfaction) and two affective processes (positive affect and negative affect) (Diener and Emmons, 1985). On one side, the affective dimension can be identified with emotions and affections, such as worry or boredom among others. On the contrary, the cognitive dimension is related to evaluative judgments of life satisfaction and its specific areas (Diener and Emmons, 1985). In line with this, Campbell et al. (1976) related the cognitive and affective dimensions of the theoretical construct, with life satisfaction and happiness, respectively. A decade later, Diener et al. (2003) synthesized that subjective well-being can be identified with components of life satisfaction, with satisfaction in specific areas of life and with the affect thereof (positive and negative). 
On the other side, existing literature shows that school is an important factor determining happiness in teenagers, since they invest most part of their life in the academic environment (Roeser and Eccles, 2000). The relationship between life satisfaction and the diverse variables of school and educations, such as academic commitment (Lewis et al., 2011), perceived academic competence (Suldo and Huebner, 2006), auto efficiency (Maddux, 2002), disruptive behavior (Suldo and Huebner, 2004), and the academic performance (Gilman and Huebner, 2006; Vecchio et al., 2007), have been extensively researched, finding contradictory results regarding this variable.

It has been proven that the satisfaction/dissatisfaction with physical education (PE) predicts a positive or negative satisfaction with school (Baena-Extremera and Granero-Gallegos, 2015) and that music students obtain higher values of life satisfaction than those who study mathematics, geography, or language (Gültekin and Aricioğlu, 2016). This therefore opens up a new field of study, due to the existence of a relationship between satisfaction on several subjects, with the academic environment and even academic performance (Baños et al., 2019).

To understand this relationship, understanding the motivational theories is fundamental. Among these theories is the self-determination theory (Deci and Ryan, 1985), along with the variables that underline it. For example, GraneroGallegos et al. (2012) found that students with high levels of satisfaction/or those that view PE as a fun subject were highly intrinsically motivated individuals, who valued the effort and work required in $\mathrm{PE}$, with the objective to improve and to give more value to the subject. In line with this, Baños et al. (2017) show that when a student experiences a class situation where fun and/or boredom is promoted, it has a direct influence on the student's performance and can have successful results on their learning process or on the contrary lead to the abandonment of the education system. In this paper, the important role of the professor can be appreciated, as the work design can be a key element in the abandonment or the academic commitment of students (Catano and Harvey, 2011). With this in mind, the influence of the teacher is hugely relevant, as the teacher can have a direct influence on school satisfaction (Baena-Extremera and Granero-Gallegos, 2015) as well as the life satisfaction of a student.

In relation to this, the quality of a students' educational experience is greatly influenced by the teacher's experience inside the classroom (Hill et al., 2003; Yair, 2008; BaenaExtermera et al., 2013) and their teaching skills. However, it is well known that teaching is multidimensional as well as complex (Wang et al., 2011), where teachers face and respond to a series of factors that could affect the students and the teaching-learning process, for example, the characteristics of the course, classroom management, and the teacher-student interaction (Young and Shaw, 1999; Khine, 2005). Therefore, to improve teacher competence, a series of basic competencies should be broken down, with specific and observable aspects for teachers, that help improve the learning process in the classroom (Denyer et al., 2007) and influences related to aspects of motivation and learning. The efficiency of such competences could vary according to each student's personality, some requiring a smart teacher, others a perfectionist, or a careful, encouraging, and loving teacher, but above all, a teacher who has the ability to amuse, enthuse, be affective, open, and caring (Moreno, 2009). Competencies like the knowledge a teacher possesses on the subject, the clarity of their presentation, and how they interact with students as well as creativity are positively related to the satisfaction and motivation of students (Sang et al., 2013). Thus, the way in which a teacher plans and organizes PE classes, adapting to the needs of their students, may influence student satisfaction at school (Baena-Extremera and Granero-Gallegos, 2015).

Considering all the above, the importance of this research lies in studying the influence of a PE teacher's competencies has on student satisfaction. Thus, the hypothesis of this study is that a competent teacher will help students achieve school satisfaction in PE and, at the same time, promote life satisfaction. Considering this hypothesis, the aim of this study is to analyze how a PE teacher's competencies can predict school satisfaction and, in turn, the life satisfaction of secondary school students.

\section{METHODS}

\section{Participants}

The selection of the sample was of a non-probabilistic type and according to the case on which the students could be accessed. A total of 890 high school (HS) and bachelor $(\mathrm{BACH}) \mathrm{PE}$ students (442 males $=49.7 \%$, age range $=15.00$, $\mathrm{DT}=2.00$; and 448 females $=50.3 \%$, age range $=15.00$; DT $=2.00$ ), belonging to five public and private schools in the Region of Murcia and the Region of Alicante (Spain). In total, 152 students belonged to $1^{\circ}$ grade HS (17.1\%), 160 $(18.0 \%)$ of $2^{\circ}$ grade HS, $182(20.4 \%)$ of $3^{\circ}$ grade HS, 186 $(20.9 \%)$ of $4^{\circ} \mathrm{HS}, 101(11.3 \%)$ of $1^{\circ}$ grade $\mathrm{BACH}$ and last, $109(12.2 \%)$ of $2^{\circ}$ grade $\mathrm{BACH}$.

\section{Instruments}

The following instruments were used to carry out this investigation.

\section{Physical Education Teacher Competence}

A validated Spanish version of the Evaluation of Teaching Competencies Scale by Catano and Harvey (2011) was used and adapted to PE by Baena-Extremera et al. (2015). The instrument presents eight items that measure the student's perception of the teacher's effectiveness. The students were asked to indicate the degree of agreement with the items, and the responses were collected using a scale of polyatomic items ranging from low (1-2), medium (3-4-5), and high (6-7). The eight constructs that this instrument evaluates are communication, conscience of work, creativity, feedback, individual consideration of the student, professionalism, problem resolution, and social conscience.

\section{Satisfaction With the School}

The questionnaire of intrinsic satisfaction was employed and translated to Spanish and validated by Castillo et al. (2001) 
from the Intrinsic Satisfaction Classroom Scale, by Nicholls et al. (1985), Nicholls (1989), and Duda and Nicholls (1992). This instrument presents eight items that measure the scale of satisfaction with school, with two subscales that measure satisfaction/fun (five items) and boredom with school (three items). The scale was used for the phrase "Tell us your degree of disagreement or agreement in relation with the next affirmations, in reference of all of your school subjects." Responses were collected through a scale of polyatomic items ranging between 1 (totally disagree) and 5 (totally agree).

\section{Satisfaction With Life}

The questionnaire used was translated to Spanish and validated by Cabañero et al. (2004) of Diener et al. (1985) and is composed of five items that measure only one factor. This instrument uses a five-point polyatomic scale of items, ranging from (1) totally disagree to (5) totally agree.

\section{Procedure}

The design of this work is non-experimental, sectional, descriptive, and predictive. For the development of this study, written informed consent was obtained from the educational centers, teachers, and parents/tutors, and the intention and objectives of the study was provided.

After obtaining the relevant permissions, data were collected. The participants were informed of the study's purpose, the voluntary nature of their participation, and the confidential treatment of their answers. They were told that there were no right or wrong answers and were asked for their utmost sincerity.

The questionnaires were completed in a classroom in about 25-30 min with the same researcher always present and who could be consulted regarding any doubts during the process, respecting the declaration of Helsinki (Helsinki Declaration World Medical Association, 2013).

\section{Data Analysis}

An analysis of normality in multiple variants was conducted.

For this, a normality test based on relative multivariant kurtosis (RMK) of the PRELIS of the LISREL 9.90 program was conducted. Given the normality, a Confirmatory Factor Analysis (CFA) to study the adaptation of such instruments to the samples used in this study was conducted. Multiple reliability and validity indexes were calculated, such as Cronbach's alpha, the compose reliability, and average variability extracted (AVE) for each instrument. A correlation analysis between the instruments used was carried out afterwards, as well as diverse models of structural equations, to answer the objective of this study. The calculations were carried out with the statistical package SPSS v.11 and LISREL 8.80 .

\section{RESULTS}

\section{Analysis of Data Normality}

In Table 1, we can observe the normality data of the measuring instruments, where finally, the data prove abnormal behavior.
TABLE 1 | Values of the multivariate normality test.

\begin{tabular}{lcccc}
\hline & $\begin{array}{c}\text { Multivariant } \\
\text { normalized } \\
\text { Kurtosis }\end{array}$ & $\begin{array}{c}\text { Mardia-based- } \\
\text { Kappa }\end{array}$ & Higher limit & Lower limit \\
\hline ECTS & 51.2439 & 0.488 & 1.027 & 0.973 \\
SWS & 6.5740 & 0.147 & 1.034 & 0.966 \\
SWL & 14.788 & 0.237 & 1.045 & 0.955 \\
\hline
\end{tabular}

ECTS, Evaluation of Teaching Competencies Scale; SWS, satisfaction with school; SWL, satisfaction with life.

The values of RMK for the Evaluation of Teaching Competencies Scale ranged from 1.488 and from 1.123 to 1.237 for the satisfaction with school and life satisfaction, respectively.

\section{Confirmatory Factor Analysis}

First, the CFA of each instrument to determine the validity and reliability of the sample used in this study was conducted. The results (Table 2) were acceptable within the limits established in $x^{2} /$ gl (Bentler, 1989; Tabachnick and Fidell, 2007), in GFI (Hooper et al., 2008), CFI, IFI, NFI, NNFI (Hu and Bentler, 1995), and RMSEA (Cole and Maxwell, 2003; Chen et al., 2008).

\section{Reliability and Validity Analysis}

As some dimensions of the instruments are composed by only a few items, the Cronbach's alpha represents some limitations according to Ventura-León and Caycho-Rodríguez (2017). For this reason and due to the recommendation of Domínguez-Lara and Merino-Soto (2015), the reliability was calculated by the $\omega$ of McDonald. Unlike the alpha Cronbach coefficient, it considers the factorial load, which makes the calculus more stable and reflects the true level of reliability without relying on the number of items in the dimension (see Ventura-León and Caycho-Rodríguez, 2017). Values of internal consistency $(\omega)$ are acceptable between 0.70 and 0.90 (Campo-Arias and Oviedo, 2008), although Katz (2006) can accept values from $>0.65$.

In Table 3, an analysis of each model is presented: the Cronbach's alpha values, compound reliability, AVE, the average and typical deviation of Evaluation of Teaching Competencies Scale, satisfaction with school, boredom with school, and life satisfaction. As can be observed, all the indexes of reliability, AVE, and all $\alpha$, which are above the acceptable values according to Dunn et al. (2014) and Hair et al. (2009), emphasize that the compound reliability is considerably more appropriate than the Cronbach's alpha in ordinal scale types because they do not depend on the number of attributes associated with each concept (Vandenbosch, 1996), as the values are more acceptable for each factor.

\section{Correlation Analysis}

In Table 4, we can see how teacher competence maintains a positive and significant correlation with satisfaction with life $\left(0.119^{* *}\right)$ and satisfaction with school $\left(0.093^{* *}\right)$ but remains negative with the ABU. The satisfaction with school presents a negative and significant correlation with the opposite factor 
TABLE 2 | Adjustment fit indices of each model.

\begin{tabular}{|c|c|c|c|c|c|c|c|c|c|c|}
\hline & $x^{2}$ & gl & $x^{2} / g l$ & $p$ & GFI & CFI & IFI & NFI & NNFI & RMSEA \\
\hline ECTS & 60.45 & 27 & & 0.000 & 0.99 & 0.98 & 0.98 & 0.96 & 0.97 & 0.03 \\
\hline SWS & 78.78 & 19 & 4.14 & 0.000 & 0.99 & 0.94 & 0.94 & 0.92 & 0.91 & 0.068 \\
\hline SWL & 18.42 & 5 & & 0.002 & 0.99 & 0.99 & 0.99 & 0.98 & 0.98 & 0.05 \\
\hline
\end{tabular}

$x^{2}$, Chi-square; gl, degrees of freedom; p, significance; GFI, goodness-of-fit index; CFI, comparative fit index; IFI, adjustment index; NFI, normalized adjustment index; NNFI, non-normative adjustment index; RMSEA, root-mean squared approximation; ECTS, Evaluation of Teaching Competencies Scale; SWS, satisfaction with school; SWL, satisfaction with life.

TABLE 3 | Scale reliability and convergent validity.

\begin{tabular}{lcccccc}
\hline & $\boldsymbol{M}$ & SD & $\begin{array}{c}\text { Composite } \\
\text { reliability }\end{array}$ & AVE & $\boldsymbol{\alpha}$ & $\boldsymbol{\omega}$ \\
\hline ECTS & 5.49 & 0.96 & 0.90 & 0.50 & 0.85 & 0.86 \\
SWS & 3.16 & 0.95 & 0.83 & 0.50 & 0.76 & 0.80 \\
BWS & 2.98 & 0.85 & 0.75 & 0.50 & 0.69 & 0.71 \\
SWL & 3.54 & 0.87 & 0.87 & 0.57 & 0.83 & 0.81 \\
\hline
\end{tabular}

M, mean; SD, standard deviation; AVE, average variance extracted; $\alpha$, Crombach's alpha; $\omega$, McDonald's omega; ECTS, Evaluation of Teaching Competencies Scale; SWS, satisfaction with school; SWL, satisfaction with life.

TABLE 4 | Correlation analysis between the variables.

\begin{tabular}{lcccc}
\hline & $\mathbf{1}$ & $\mathbf{2}$ & $\mathbf{3}$ & $\mathbf{4}$ \\
\hline 1. ECTS & - & $0.093^{\star *}$ & -0.023 & $0.119^{\star *}$ \\
2. SATD & & - & $-0.546^{\star *}$ & $0.272^{\star *}$ \\
3. ABUE & & - & $-0.201^{\text {** }}$ \\
4. SATV & & & - \\
\hline
\end{tabular}

ECTS, Evaluation of Teaching Competencies Scale; SWS, satisfaction with school: SWL, satisfaction with life. ${ }^{*} p<0.05 ;{ }^{* *} p<0.01$.

on its scale $\left(-0.546^{* *}\right)$ and positive with satisfaction with life $\left(0.272^{* *}\right)$. The boredom with school finally correlates negative and significantly with satisfaction with life $\left(-0.201^{* *}\right)$.

\section{Prediction of Satisfaction With Student Life}

In accordance with the objective of this study, different models have been hypothesized to test which would adjust better according to the recommendation of Markland (2007). According to the correlations, the model that better predicted the satisfaction with the student life was approved. The structural regression models were evaluated through the combination of the adjustment indexes previously explained, with their values being $x^{2} / \mathrm{gl}=4.32$, GFI $=0.96$, $\mathrm{CFI}=0.92$, $\mathrm{IFI}=0.92$, NFI $=0.95$, NNFI $=0.96$, and $\mathrm{RMSEA}=0.06$. These values adjust perfectly to the acceptable parameters (Bentler, 1989; Tabachnick and Fidell, 2007; Hooper et al., 2008, among others). According with the Figure 1, we can observe gamma, beta, lambda-x, lambda-y, and theta delta and theta épsilon values (Figure 1). In it, we can appreciate how the Evaluation of Teaching Competencies Scale positively predicts the impact of the satisfaction with school $(\gamma=0.94)$, being negative for boredom with school $(\gamma=-0.79)$, satisfaction with school, predicts at the same time the satisfaction with life in a positive way $(\beta=0.50)$, being the prediction of boredom with school $(\beta=0.05)$. Finally, the estimated parameters were considered significant when the value associated with value $t$ is greater than $1.96(p<0.05)$ and all items showed individual reliability values of $(\lambda)>0.05$.

\section{DISCUSSION}

The objective of this study was to analyze how a PE teacher's competencies can predict the satisfaction with school, and how these, at the same time, predict the life satisfaction of HS and $\mathrm{BACH}$ students. The importance of this research lies in the influence that a PE teacher can generate on the subjective wellbeing of adolescents, not only in the academic field but also in other areas of life. In addition, adolescence is a stage of life that carries profound changes, in which friend and family influences are transformed and where decision-making has a greater impact on adult life (Maršanić et al., 2014). Failing school and even the increasing suicide rate at this stage of life are fundamental aspects of this study, similar to those already mentioned (Kosik et al., 2017).

We emphasize that the three scales, the Evaluation of Teaching Competencies Scale, satisfaction with school and satisfaction with life, obtained viable and reliable results.

The obtained results in this study demonstrate positive and significant correlations between teacher competencies with satisfaction with school and satisfaction with life and had no correlation with boredom with school, although it did find signs of a limited negative relation. These results showed that a PE teacher who is a good communicator, with work and social conscience, a creative and problem resolution capacity, who provides feedback, who has good individual consideration with a student, and who in conclusion is professional, can affect satisfaction not only through fun and how satisfied they are with school but also can also have repercussions in their satisfaction with life. Similar results were found by Kuzmanovic et al. (2013) who showed that students were satisfied when the teacher was available to solve problems, showing consideration, and providing feedback. So, a good teacher is distinguished by his/her students, as a good stimulator, innovator, enthusiastic, with a good sense of humor, and who is self-reflective, and supportive of diversity (Johnstone, 2005; Khine, 2005; Yair, 2008; Delaney et al., 2009).

Satisfaction with school is significantly positively correlated to satisfaction with life; however, it is significantly negatively correlated to boredom with school, and this, at the same time, is significantly negatively correlated with satisfaction with life. Although it has been proven that teenagers who are perceived as happier, learn faster, behave better, and show greater 


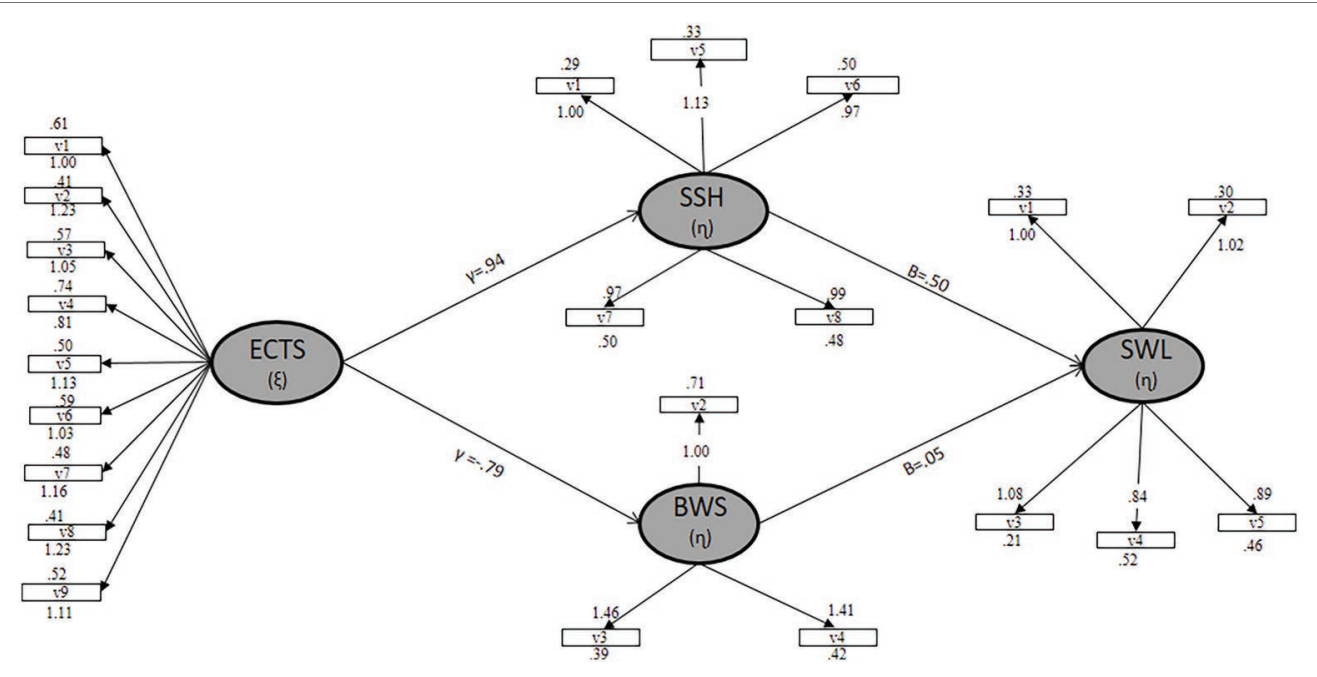

FIGURE 1 | Exogenous variable ECTS ( $\xi$ ), Evaluation of Teaching Competencies Scale; endogenous bariable SSH ( $\eta$ ), dimension of satisfaction with school; endogenous variable BWS $(\eta)$, dimension boredom with school; endogenous variable SWL $(\eta)$, satisfaction with life; $\gamma$, gamma values; $\beta$, beta values.

commitment and academic performance (Noddings, 2003; Ben-Arieh, 2008; Castro, 2011; Baena-Extremera and GraneroGallegos, 2013; Lyons and Huebner, 2016), the school plays an important role in their subjective well-being, due to the time they spend on academics; therefore, if they find it monotonous and boring, their happiness could be diminished. This input was reflected in the results obtained in this present study, where a student who is unsatisfied at school is related to low levels of satisfaction with life. In line with this, Lyons and Huebner, 2016 found similar results, since students who became bored at school showed less school commitment and more dissatisfaction with their life. Considering this, the correct planning of classroom sessions to avoid monotonous and boring classes is of utmost importance and can increase the levels of satisfaction with life (Quinn and Duckworth, 2007).

In the results of the predictive model, it could be observed how the PE teaching competencies positively predicted the satisfaction with school, and in turn, the satisfaction with life, obtaining similar results to the studies realized by BaenaExtremera et al. (2015). This helped to understand the weight that a PE teacher has on the educative system and on the life of the students, where the difference of being a competent teacher or not, could directly influence the satisfaction or boredom of a student and therefore indirectly influence life satisfaction (Baños et al., 2017). It is also known that the excellence and quality of the institution, as well as the professionalism of the teacher, with traits such as fairness and impartiality, predicts the satisfaction of the student in the classroom and the satisfaction with the teaching quality (Elliot and Shin, 2002) emphasizing the need for good teaching, the setting of clear goals, suitable evaluation methods depending the level of the students, planning of appropriate workload, and having ideal general competencies for teaching (Ginns et al., 2007). However, if teachers do not produce the sufficient impact on their students (Cameron and Lovett, 2015) and the student's perception of the incompetencies of their PE teacher predicts boredom with school, they will not find the prediction of satisfaction with life. These results are important, as an unsatisfied student increases the possibility of failing school or even abandoning school (Elmore and Huebner, 2010) and increases the probability of suicide in teenagers (Singer et al., 2018). For this reason, it is important to have good teaching practices, emphasizing the influence that a PE teacher can have on their students if they are well prepared, avoiding monotonous classes, with organized planning, where the educator gives autonomy to the students and where sessions approach the students' interests (Delaney et al., 2009; Calderón et al., 2013; Lee et al., 2015; Lebrero et al., 2019). By doing this, motivation for PE classes will likely improve (Baena-Extremera et al., 2013), affecting the school and faculty (Aubert et al., 2014), improving the results on the PISA report, alarming on the Spanish education system (Casquero and Navarro, 2010).

Finally, the advances presented in this study with relation to previous research can be summarized. A PE teacher can positively predict the life satisfaction of students through the subject they teach and can especially influences stages where they experience big personal changes, morphological and psychological. Therefore, the original contribution of this study is the impact a PE teacher has not only with regard to the physical activity in a teenager's spare time (Wallhead and Buckworth, 2004; Baena-Extermera et al., 2016) but also on the satisfaction with school and life satisfaction life.

\section{Limitations and Strengths}

Future research should consider using different levels and ages and should even consider analyzing these variables in other subjects. Another limitation of this study is its design; a future possibility is to carry out a quasi-experiment, considering the school organization. Nevertheless, the strength of this study is the large number of participants used and the originality of 
the investigation as very few studies on this topic are present in the current literature.

\section{DATA AVAILABILITY STATEMENT}

The datasets generated for this study are available on request to the corresponding author.

\section{ETHICS STATEMENT}

Ethical review and approval were not required for the study on human participants in accordance with the local legislation

\section{REFERENCES}

Argyle, M. (1987). The psychology of happiness. London: Roytledge.

Aubert, A., Bizkarra, M., and Calvo, J. (2014). Actuaciones educativas de éxito desde la Educación Física. Retos 25, 144-148.

Baena-Extermera, A., Granero-Gallegos, A., Pérez-Quero, F. J., Bracho-Amador, C., and Sánchez-Fuentes, J. A. (2013). Motivation and motivational climate as predictors of perceived importance of physical education in Spain. S. Afr. J. Res. Sport Phys. Educ. Recreat. 35, 1-13.

Baena-Extermera, A., Granero-Gallegos, A., Ponce-de-Leon-Elizondo, A., Sanz-Arazuri, E., Valdemoros-San-Emeterio, M. D., and Martínez-Molina, M. (2016). Psychological factors related to physical education clases as predictors of students'intention to partake in leisure-time physical activity. Ciencia \& Saude Coletiva 21, 1105-1112. doi: 10.1590/1413-81232015214. 07742015

Baena-Extremera, A., and Granero-Gallegos, A. (2013). Efecto de un programa de Educación de Aventura en la orientación al aprendizaje, satisfacción y autoconcepto en secundaria. Rev. Ibero. Diag. Ev. - e - Aval. Psicol. 36, 163-187.

Baena-Extremera, A., and Granero-Gallegos, A. (2015). Modelo de predicción de la satisfacción con la Educación Física y la escuela. Rev. Psico. 20, 177-192. doi: 10.1387/RevPsicodidact.11268

Baena-Extremera, A., Granero-Gallegos, A., and Martínez-Molina, M. (2015). Validación española de la Escala de Evaluación de la Competencia Docente en Educación Física de secundaria. Cuad. Psicol. Deporte 15, 113-122. doi: 10.4321/S1578-84232015000300011

Baena-Extremera, A., Granero-Gallegos, A., Sánchez-Fuentes, J. A., and MartínezMolina, M. (2013). Apoyo a la autonomía en Educación Física: Antecedentes, diseño, metodología y análisis de la relación con la motivación en estudiantes adolescentes. Retos 24, 46-49.

Baños, R., Barretos-Ruvalcaba, M., and Baena-Extremera, A. (2019). Protocolo de estudio de las variables académicas, psicológicas y de actividad física que influyen en el rendimiento académico de adolescentes mexicanos y españoles. Espiral 12, 89-99. doi: 10.25115/ecp.v12i25.2480

Baños, R., Ortiz-Camacho, M. M., Baena-Extremera, A., and Tristán-Rodríguez, L. (2017). Satisfacción, motivación y rendimiento académico en estudiantes de secundaria y bachillerato: antecedentes, diseño, metodología y propuesta de análisis para un trabajo de investigación. Espiral 10, 40-50. doi: 10.25115/ ecp.v10i20.1011

Ben-Arieh, A. (2008). The child indicators movement: past, present, and future. Child Indic. Res. 1, 3-16. doi: 10.1007/s12187-007-9003-1

Bentler, P. M. (1989). EQS structural equations program manual. Los Angeles, CA: BMDP.

Cabañero, M. J., Richart, M., Cabrero, J., Orts, M. I., Reig, A., and Tosal, B. (2004). Fiabilidad y validez de la Escala de Satisfacción con la Vida de Diener en una muestra de mujeres embarazadas y puérperas. Psicothema 16, 448-455.

Calderón, A., Martínez, D., and Martínez, I. (2013). Influencia de la habilidad física percibida sobre la actitud del alumnado tras una unidad didáctica basada en educación deportiva. Retos 24, 16-20. and institutional requirements. Written informed consent from the participants was not required to participate in this study in accordance with the national legislation and the institutional requirements.

\section{AUTHOR CONTRIBUTIONS}

$\mathrm{RB}$ and $\mathrm{AB}-\mathrm{E}$ conceived the hypothesis of this study and analyzed the data. $\mathrm{RB}, \mathrm{AB}-\mathrm{E}$, and $\mathrm{MO}-\mathrm{C}$ participated in data collection and wrote the paper with the most significant input from AB-E. All authors contributed to data interpretation of statistical analysis and read and approved the final manuscript.

Cameron, M., and Lovett, S. (2015). Sustaining the commitment and realising the potential of highly promising teachers. Teach. Teach. 21, 150-163. doi: 10.1080/13540602.2014.928132

Campbell, A., Converse, P. E., and Rodgers, W. L. (1976). The quality of American life: Perception; evaluations, and satisfactions. New York: Russell Sage.

Campo-Arias, A., and Oviedo, H. C. (2008). Propiedades psicométricas de una escala: la consistencia interna. Rev. Sal. Pública 10, 831-839. doi: 10.1590/ S0124-00642008000500015

Casquero, A., and Navarro, M. L. (2010). Determinantes del abandono escolar en España. Rev. Educ. Número Extraordin. 1, 191-223.

Castillo, I., Balaguer, I., and Duda, J. L. (2001). Las perspectivas de meta de los adolescentes en el contexto deportivo. Psicothema 14, 280-287.

Castro, A. (2011). Las rutas de acceso al bienestar. Relaciones entre bienestar hedónico y eudaemónico. Un estudio en población Argentina. Rev. Iber Diag. Eval.Psicol. 31, 37-57.

Catano, V. M., and Harvey, S. (2011). Student perception of teaching effectiveness: development and validation of the evaluation of teaching competencies scale (ETCS). Assess. Eval. High. Educ. 36, 701-717. doi: 10.1080/02602938.2010.484879

Chen, F., Curran, P. J., Bollen, K. A., Kirby, J., and Paxton, P. (2008). An empirical evaluation of the use of fixed cutoff points in RMSEA test statistic in structural equation models. Sociol. Meth. Res. 36, 462-494. doi: $10.1177 / 0049124108314720$

Cole, D. A., and Maxwell, S. E. (2003). Testing mediational models with longitudinal data: questions and tips in the use of structural equation modeling. J. Abnor. Psychol. 112, 558-577. doi: 10.1037/0021-843X.112.4.558

Deci, E. L., and Ryan, R. M. (1985). Intrinsic motivation and self-determination in human behavior. New York: Plenum.

Delaney, J., Johnson, A., Johnson, T., and Treslan, D. (2009). Students' perceptions of effective teaching in higher education. Paper presented at the Edge Conference, Canada.

Denyer, M., Furnemont, J., Poulain, R., and Vanloubbeeck, G. (2007). Las competencias en la educación, un balance. México: Fondo de Cultura Económica.

Diener, E. (1984). Subjective well-being. Psychol. Bull. 95, 542-575. doi: 10.1037/0033-2909.95.3.542

Diener, E., and Emmons, R. A. (1985). The independence of positive and negative affect. J. Pers. Assess. 99, 91-95.

Diener, E. D., Emmons, R. A., Larsen, R. J., and Griffin, S. (1985). The satisfaction with life scale. J. Pers. Assess. 49, 71-75. doi: 10.1207/s15327752jpa4901_13

Diener, E., Oishi, S., and Lucas, R. E. (2003). Personality, culture and subjective well-being: emotional and cognitive evaluations of life. An. Rev. Psychol. 54, 403-425. doi: 10.1146/annurev.psych.54.101601.145056

Domínguez-Lara, S. A. D., and Merino-Soto, C. M. (2015). ¿Por qué es importante reportar los intervalos de confianza del coeficiente alfa de Cronbach? Rev. Cien. Soc. 13, 1326-1328.

Duda, J. L., and Nicholls, J. G. (1992). Dimensions of achievement motivation in schoolwork and sport. J. Educ. Psychol. 84, 290-299. doi: 10.1037/ 0022-0663.84.3.290

Dunn, T. J., Baguley, T., and Brunsden, V. (2014). From alpha to omega: a practical solution to the pervasive problem of internal consistency estimation. Brit. J. Psychol. 105, 399-412. doi: 10.1111/bjop.12046 
Elliot, K., and Shin, D. (2002). Student satisfaction: an alternative approach to assessing this important concept. J. High. Educ. Policy Manag. 24, 197-209. doi: $10.1080 / 1360080022000013518$

Elmore, G. M., and Huebner, E. S. (2010). Adolescents satisfaction with school experiences: relationships with demographics, attachment relationships, and school engagement behavior. Psychol. Sch. 47, 525-537. doi: 10.1002/pits.20488

Gilman, R., and Huebner, E. S. (2006). Characteristics of adolescents who report very high life satisfaction. J. Youth Adoles. 35, 311-319. doi: 10.1007/ s10964-006-9036-7

Ginns, P., Prosser, M., and Barrie, S. (2007). Students' perceptions of teaching quality in higher education: the perspective of currently enrolled students. Stud. High. Educ. 32, 603-615. doi: 10.1080/03075070701573773

Granero-Gallegos, A., Baena-Extremera, A., Pérez-Quero, F. J., Ortiz-Camacho, M. M., and Bracho-Amador, C. (2012). Analysis of motivational profiles of satisfaction and importance of physical education in high school adolescents. J. Sports Sci. Med. 11, 614-623.

Gültekin, F., and Aricioğlu, A. (2016). The relationship between the life satisfaction, hope and anxiety of senior students. J. Coun. Educ. 5, 57-74. doi: 10.5430/ ijhe.v5n2p275

Hair, J. F., Black, W. C., Babin, B. J., and Anderson, R. E. (2009). Multivariate data analysis. New York: Pearson Prentice Hall.

Helsinki Declaration World Medical Association (2013). Available at: www.isciii. es/ISCIII/es/contenidos/fd-investigacion/fd-evaluacion/fd-evaluacion-eticainvestigacion/Declaracion-Helsinki-2013-Esp.pdf (Accessed August 06, 2019).

Hill, Y., Lomas, L., and MacGregor, J. (2003). Students' perceptions of quality in higher education. Qual. Assur. Educ. 11, 15-20. doi: 10.1108/09684880310462047

Hooper, J. D., Coughlan, M. R., and Mullen, M. (2008). Structural equation modeling: guidelines for determining model fit. Elec J. Bus. Res. Meth. 6, 53-60.

$\mathrm{Hu}$, L.-T., and Bentler, P. (1995). "Evaluating model fit" in Structural equation modeling. Concepts, issues, and applications. ed. R. H. Hoyle (London: Sage), 76-99.

Johnstone, A. (2005). Evaluation of teaching. Higher Education Academy, Physical Sciences Centre, University of Hull. Available at: www.physsci.heacademy.ac.uk (Accessed July 17, 2018).

Katz, M. H. (2006). Multivariable analysis. 2nd Edn. Cambridge: Cambridge University Press.

Khine, M. S. (2005). Self-perceived and students perceptions of teacher interaction in the classrooms. Paper presented at the Conference on Redesigning Pedagogy: Research, Policy and Practice, Singapore.

Kosik, R., Fan, A., Mandell, G., Su, T. P., Nguyen, T., Chen, J., et al. (2017). Academic performance in childhood and the risk of attempting suicide as an adult. Europ. J. Psych. 31, 73-79. doi: 10.1016/j.ejpsy.2017.03.002

Kuzmanovic, M., Savic, G., Popovic, M., and andMartic, M. (2013). A new approach to evaluation of university teaching considering heterogeneity of students' preferences. High. Educ. 66, 153-171. doi: 10.1007/s10734-012-9596-2

Lebrero, I., Alamagro, B. J., and Sáenz-López, P. (2019). Estilos de enseñanza participativos en las clases de Educación Física y su influencia sobre diferentes aspectos psicológicos. Espiral 12, 30-39. doi: 10.25115/ecp.v12i25.2286

Lee, H. H., Kim, G. M. L., and Chan, L. L. (2015). Good teaching: what matters to university students. Asia Pac. J. Educ. 35, 98-110. doi: 10.1080/ 02188791.2013.860008

Lewis, A. D., Huebner, E. S., Malone, P. S., and Valois, R. F. (2011). Life satisfaction and student engagement in adolescents. J. Youth Adoles. 40, 249-262. doi: 10.1007/s10964-010-9517-6

Lyons, M., and Huebner, E. (2016). Academic characteristics of early adolescentswith higher levels of life satisfaction. App. Res. Qual. Life 11, 757-771. doi: 10.1007/s11482-015-9394-y

Maddux, J. E. (2002). "Self-efficacy: the power of believing you can" in Handbook of positive psychology. eds. C. R. Snyder and S. J. Lopez (New York: Oxford University Press), 277-287.

Markland, D. (2007). The golden rule is that there are no golden rules: a commentary on Paul Barrett's recommendations for reporting model fit in structural equation modelling. Personal. Individ. Differ. 42, 851-858. doi: 10.1016/j.paid.2006.09.023

Maršanić, V. B., Margetić, B. A., Zečević, I., and andHerceg, M. (2014). The prevalence and psychosocial correlates of suicide attempts among inpatient adolescent offspring of Croatian PTSD male war veterans. Child Psych. Hum. Dev. 45, 577-587. doi: 10.1007/s10578-013-0426-2
Méndez-Giménez, A., Cecchini-Estrada, J. A., Fernández-Rio, J., Méndez-Alonso, D., and Prieto-Saborit, J. A. (2017). Metas de logro 3x2, motivación autodeterminada y satisfacción con la vida en educación secundaria. Rev. Psicod. 22, 150-156. doi: 10.1016/j.psicod.2017.05.001

Moreno, C. (2009). Effectiveteachers-professional and personal skills. ENSAYOS, Revista de la Facultad de Educación de Albacete, 24. Available at: http:// www.uclm.es/ab/educacion/ensayos (Accessed January 22, 2019).

Nicholls, J. G. (1989). The competitive ethos and democratic education. Cambridge, Mass: Harvard University Press.

Nicholls, J. G., Patashnick, M., and Nolen, S. B. (1985). Adolescents' theories of education. J. Educ. Psychol. 77, 683-692. doi: 10.1037/0022-0663.77.6.683

Noddings, N. (2003). Happiness and education. New York: Cambridge University Press.

Quinn, P. D., and Duckworth, A. L. (2007). Happiness and academic achievement: Evidence for reciprocal causality. Poster session presented at the annual meeting of the American Psychological Society, Washington, DC.

Roeser, R. W., and Eccles, J. S. (2000). "Schooling and mental health" in Handbook of developmental psychopathology. 2nd Edn. eds. A. J. Sameroff, M. Lewis, and S. M. Miller (New York: Plenum), 135-156.

Salvador-Ferrer, C. (2017). Relación entre la gratitud y la satisfacción con la vida en una muestra de estudiantes españoles: el papel moderador del género. Anales Psicol. 33, 114-119. doi: 10.6018/analesps.32.3.226671

Sang, C., Ibrahim, Z., and andOwee, T. (2013). An analysis on the relationship between lecturers' competencies and students' satisfaction. Int. Educ. Stud. 7, 37-46. doi: 10.5539/ies.v7n1p37

Singer, J. B., Erbacher, T. A., and Rosen, P. (2018). School-based suicide prevention: a framework for evidence-based practice. Sch. Ment. Health 11, 54-71. doi: 10.1007/s12310-018-9245-8

Suldo, S. M., and Huebner, E. S. (2004). Does life satisfaction moderate the effects of stressful events on psychopathological behavior during adolescence? Sch. Psychol. Q. 19, 93-105. doi: 10.1521/scpq.19.2.93.33313

Suldo, S. M., and Huebner, E. S. (2006). Is extremely high life satisfaction during adolescence advantageous? Soc. Indic. Res. 78, 179-203. doi: 10.1007/ s11205-005-8208-2

Tabachnick, B. G., and Fidell, L. S. (2007). Using multivariate statistics, 5th Edn. New York: Allyn and Bacon.

Vandenbosch, M. (1996). Confirmatory compositional approaches to the development of product spaces. Eur. J. Mark. 30, 23-46. doi: 10.1108/03090569610107418

Vecchio, G., Gerbino, M., Pastorelli, C., Del Bove, G., and andCaprara, G. (2007). Multi-faceted self-efficacy beliefs as predictors of life satisfaction in late adolescence. Pers. Individ. Differ. 43, 1807-1818. doi: 10.1016/j. paid.2007.05.018

Ventura-León, J. L., and Caycho-Rodríguez, T. (2017). El coeficiente Omega: un método alternativo para la estimación de la confiabilidad. Rev. Cien. Soc. 15, 625-627.

Wallhead, T., and Buckworth, J. (2004). The role of physical education in the promotion of youth physical activity. Quest 56, 285-301. doi: 10.1080/ 00336297.2004.10491827

Wang, J., Lin, E., and Spalding, E. (2011). Quality teaching and teacher education: a kaleidoscope of notions. J. Teach. Educ. 62, 331-338. doi: 10.1177/ 0022487111409551

Yair, G. (2008). Can we administer the scholarship of teaching? Lessons from outstanding professors in higher education. High. Educ. 55, 447-459. doi: 10.1007/s10734-007-9066-4

Young, S., and Shaw, D. G. (1999). Profiles of effective college and university teachers. J. High. Educ. 70, 670-686. doi: 10.2307/2649170

Conflict of Interest: The authors declare that the research was conducted in the absence of any commercial or financial relationships that could be construed as a potential conflict of interest.

Copyright (c) 2019 Baños, Baena-Extremera and Ortiz-Camacho. This is an open-access article distributed under the terms of the Creative Commons Attribution License (CC $B Y)$. The use, distribution or reproduction in other forums is permitted, provided the original author(s) and the copyright owner(s) are credited and that the original publication in this journal is cited, in accordance with accepted academic practice. No use, distribution or reproduction is permitted which does not comply with these terms. 